Jan Mazur OSPPE

Uniwersytet Papieski

Jana Pawła II w Krakowie
Etyka pracy socjalnej w filozofii

spotkania i dialogu,

red. M. Duda, I. Rybka, H. Kaszyński,

Kraków 2017, s. 27-34

(Praca Socjalna w Teorii i Działaniu, 4).

DOI: http://dx.doi.org/10.15633/9788374386425.03

\title{
Rola i znaczenie dialogu w pracy socjalnej
}

\section{The role and meaning of dialogue in social work}

\begin{abstract}
Abstakt: Znaczenie i cel pracy socjalnej oddaje angielski termin empowerment. Oznacza on proces upodmiotowienia. Proces ten sprawia, że jednostki, rodziny, grupy czy nawet całe społeczności odzyskują kontrolę nad własną egzystencją oraz stają się aktywnymi uczestnikami życia społecznego. Empowerment to przeciwieństwo bezsilności, to aktywna postawa zmiany i partycypacji w kierunku samoodpowiedzialności oraz samodecydowania. Dla realizacji empowerment niezbędny jest kontakt pomiędzy poszczególnymi aktorami pracy socjalnej. Szczególnie ważna jest właściwa relacja pomiędzy pracownikiem socjalnym a klientem pomocy społecznej. Przejawem tej relacji, jej wstępnym warunkiem jest dialog. Przy analizie roli dialogu w pracy socjalnej wykorzystane zostały przemyślenia ks. Józefa Tischnera (1931-2000), wybitne-

Abstract: The meaning and purpose of social work is captured by the English term empowerment. It means a process. Through empowerment, individuals, families, groups or even whole communities regain control over their own existence and become active participants in social life. Empowerment is the opposite of helplessness, it is an active attitude of change and participation in the direction of responsibility for self and selfdetermination. In order to achieve empowerment, contact between the participants of social work is necessary. An appropriate relationship between the social worker and the client of social assistance is especially important. Dialogue is a manifestation of this relationship, and a prerequisite for it. When analyzing the role of dialogue in social work the thoughts of Father Józef Tischner (1931-2000) were used, the eminent
\end{abstract}


go krakowskiego filozofa, który uprawiał filozofię dialogu jako filozofię dramatu. Jest to bardzo interesująca koncepcja, wedle której człowiek ujmowany jest jako egzystencja dramatyczna.

Słowa kluczowe: praca socjalna, dialog, empowerment, filozofia dialogu, filozofia dramatu, człowiek jako egzystencja dramatyczna. philosopher from Kraków who practiced the philosophy of dialogue as a philosophy of drama. It is a very interesting concept, according to which a person is seen in terms of a dramatic existence.

Keywords: social work, dialogue, empowerment, philosophy of dialogue, philosophy of drama, human existence as dramatic.

\section{Praca socjalna i dialog}

Wypada rozpocząć od przypomnienia, że aktualnie w Polsce przyjmuje się urzędową definicję „pracy socjalnej” zapisaną w art. 6 pkt 12 Ustawy o pomocy społecznej z 12 marca 2004 roku. Wedle ustawy, przez pracę socjalną rozumie się „działalność zawodową, mającą na celu pomoc osobom i rodzinom we wzmocnieniu lub odzyskaniu zdolności do funkcjonowania w społeczeństwie poprzez pełnienie odpowiednich ról społecznych oraz tworzenie warunków sprzyjających temu celowi"'. Chodzi więc o profesjonalną pomoc w kierunku wzmocnienia lub odzyskania zdolności adresatów pomocy w funkcjonowaniu społecznym oraz tworzeniu sprzyjających ku temu warunków społecznych ${ }^{2}$. Warto w tym miejscu dodać, że znaczenie, czy raczej cel pracy socjalnej, oddaje angielski termin empowerment, oznaczający proces upodmiotowienia, podczas którego jednostki, rodziny, grupy czy nawet całe społeczności odzyskują kontrolę nad własną egzystencją oraz stają się aktywnymi uczestnikami życia społecznego. Podejmują bowiem działania zmierzające do poprawy sytuacji własnej lub swojej rodziny względnie całej wspólnoty, w które funkcjonują. Innymi słowy, „empowerment to przeciwieństwo bezsilności, to aktywna postawa zmiany i partycypacji w kierunku samoodpowiedzialności oraz samodecydowania"3.

\section{Dz. U. z 2004 r. Nr 64, poz. 953 z późn. zm.}

Zob. M. Marszałkowska, Standardy pracy socjalnej. Raport końcowy: Analiza zasobów [Projekt realizowany w ramach grantu TF052685 Poakcesyjnego Projektu Pomocy dla Obszarów Wiejskich (PARSP)], Warszawa, maj 2005, http://www.mpips.gov.pl/userfiles/ File/mps/standardyps.pdf (5.11.2016).

M. Grewiński, Od redakcji, „Empowerment o polityce aktywnej integracji” 2003, nr 1, s. 3 . 
Dla realizacji owej misji, którą kryje w sobie termin empowerment, niezbędny jest kontakt pomiędzy poszczególnymi aktorami pracy socjalnej, w szczególności chodzi o właściwą relację pomiędzy pracownikiem socjalnym a klientem pomocy społecznej. Wyrazem tej relacji, jej wstępnym warunkiem jest dialog. W tym kontekście można przywołać filozofię dialogu czy filozofię spotkania, zwłaszcza zaproponowaną przez ks. Józefa Tischnera filozofię dramatu, by dokonać swego rodzaju wglądu w rolę i znaczenie dialogu prowadzonego w ramach pracy socjalnej.

Najpierw jednak nie sposób nie wspomnieć o tym, czym jest dialog. Ogólnie przyjmuje się, że dialog oznacza rozmowę, której celem jest wymiana myśli i poglądów. Podstawowe znaczenie tego słowa wypływa z jego greckiej etymologii, na którą składają się dwa wyrazy: diá - przez, za sprawą, dzięki; lógos - słowo, nauka. Jednakże słowo lógos może oznaczać także „rozum”, „mowę” czy „język-mowę". Zatem diá lógos w dosłownym polskim tłumaczeniu brzmi „przez rozum”, „dzięki rozumowi” względnie „po rozumie”, co w gruncie rzeczy można wyrazić jako „porozumienie”. Zwykle jednak współczesne słowniki słowo „dialog" wyprowadzają z greckiego rzeczownika diálogos (rozmowa) lub czasownika w formie bezokolicznikowej dialégein (rozmawiać) ${ }^{4}$.

Dialog oznacza więc rozmowę polegającą na dobrowolnej wymianie zazwyczaj różniących się poglądów dotyczących ważnych spraw z zamiarem osiągnięcia porozumienia. Chodzi o taką rozmowę, która ma na celu wymianę zdań na jakiś temat, zaś specyfiką tej wymiany jest wzajemna konfrontacja, poznanie czy wola zrozumienia prezentowanych poglądów. W konsekwencji tego rodzaju rozmowa ma prowadzić do współdziałania w zakresie wspólnego poszukiwania konkretnej prawdy (o życiu człowieka, o jakimś zjawisku, o sytuacji, wydarzeniu itp.). Ideałem jest, by to poszukiwanie skutkowało obroną autentycznych wartości i służyło promocji sprawiedliwości i pokoju w kontekście dobra poszczególnych stron rozmowy czy dobra wspólnego.

Dialog wpisany jest w naturę ludzkiego życia, zwłaszcza życia społecznego. Z oczywistych względów wpisany jest też w naturę pracy socjalnej. Jednak nie jest on czymś zupełnie oczywistym, dającym się ująć w kategorie o charakterze ściśle racjonalnym, bo każdy człowiek dialogujący jest przecież osobą, a wiec kimś jedynym w swoim rodzaju, niepowtarzalnym, rozumnym i wolnym, mającym swoją godność. Innymi słowy, człowiek jako taki - w ujęciu personalistycznym - jest tajemnicą, która jakby wyraża się także w człowieku dialogującym.

4 Por. J. Mazur, Per dialogum od veritatem. Podstawy dialogu społecznego - perspektywa chrześcijańska, Kraków 2014, s. 10nn. 


\section{Człowiek jako egzystencja dramatyczna}

Odnośnie do dialogu w pracy socjalnej czy w odniesieniu do samego człowieka dialogującego wiele twórczej intuicji kryje w sobie ujęcie wyłaniające się z rozważań wybitnego krakowskiego filozofa ks. Józefa Tischnera (1931-2000). Utrzymuje on, że człowiek jest egzystencją dramatyczną. Cóż to stwierdzenie oznacza? Wedle ks. Tischnera, słowo „dramat” zawsze wskazuje na człowieka, który żyje w ten sposób, że bierze udział w dramacie tworzonym przez trzy elementy: otwarcie na innego człowieka, otwarcie na scenę dramatu i otwarcie na przepływający czas. Ciągłość czasu, w którym żyje człowiek jako istota dramatyczna, jest jakby substancją dramatu, zaś jego sceną jest świat będący „pod naszymi stopami”s.

Owa scena życia to - wedle Józefa Tischnera - przede wszystkim płaszczyzna spotkań i rozstań - przestrzeń wolności, w której człowiek szuka dla siebie domu, chleba, Boga i w której w końcu zastaje go śmierć. Doświadcza tej sceny przez jej uprzedmiotowianie, czyli zamianę jej na przestrzeń wypełnioną przedmiotami, z których następnie zestawia rozmaite całości, jakie mu służą. O ile otwarcie człowieka na scenę dramatu ma charakter intencjonalny, o tyle zupełnie odmienny charakter ma jego otwarcie na innych uczestników tego samego dramatu. Otwarcie na drugiego człowieka ma charakter dialogiczny. Krakowski Filozof wyjaśnił to słowami:

„Inny człowiek staje wobec mnie poprzez jakieś roszczenie, w którego następstwie powstaje we mnie poczucie zobowiązania. Świadomość tego, że drugi jest obecny, dopełnia się jako świadomość roszczenia - roszczenia, które zobowiązuje. Oto do moich uszu dochodzi twoje pytanie. Jest chwila ciszy, wspólnej teraźniejszości. Oczekujesz na odpowiedź. Trzeba dać odpowiedź. To trzeba jest istotne. Dzięki niemu i w nim jesteś przy mnie obecny [...] dzięki otwarciu dialogicznemu stajesz przy mnie Ty"6.

W ujęciu Tischnera człowiek jest więc istotą dramatyczną. Do natury człowieka należy dramatyczny czas oraz intencjonalne otwarcie na scenę (świat) i dialogiczne otwarcie na innego człowieka. W myśli krakowskiego Filozofa, wpisującej się w tzw. filozofię dramatu, relacja człowiek-człowiek charakteryzuje związek dialogiczny. W związku tym naprzeciw siebie staje "pytający” i „zapytany”. Według Tischnera związek dialogiczny daje świadomość obecności drugiego człowieka, bowiem dzięki pytaniu człowiek wie, że obok niego jest drugi człowiek?

Por. J. Tischner, Filozofia dramatu, Kraków 2001, s. 8.

J. Tischner, Filozofia..., dz. cyt., s. 9-10.

J. Tischner, Filozofia..., dz. cyt., s. 16-17. 
Jednakże należy w tym miejscu zapytać o znaczenie egzystencjalne owego dramatu, który charakteryzuje filozofię dialogu (filozofię spotkania) ${ }^{8}$. Ks. Tischner, posługując się metaforą, napisał:

„Biorąc udział w jakimś dramacie, człowiek wie mniej lub bardziej jasno, że w jego rękach jest jego zguba lub ocalenie. Być istotą dramatyczną to wierzyć - prawdziwie czy nieprawdziwie - że zguba lub ocalenie są w rękach człowieka. Człowiek może nie wiedzieć, na czym polega ostatecznie jego zguba i na czym polega jego ocalenie, pomimo to może mieć świadomość, że o coś takiego w życiu chodzi. Będąc przekonanym, że zguba i ocalenie są w jego rękach, człowiek kieruje swym życiem wedle tego przeświadczenia. Przekonanie to zakłada szczególną ontologiczną strukturę człowieka: człowiek może być podmiotem dramatu, bo jest bytem-dla-siebie. [...] Ponieważ człowiek jest dla siebie, może sobie siebie przyswoić. Uczestnictwo w dramacie jest przyswajaniem siebie ze względu na nadzieję ocalenia".

\section{Dialog na scenie ludzkiego dramatu}

Zamyślenia ks. Tischnera kapitalnie wpisują się w poszukiwania sensu dialogu podejmowanego w ramach pracy socjalnej. Można przyjąć, że praca socjalna tworzy scenę ludzkiego dramatu. Na niej rozgrywa się dramat, który można by kojarzyć ze spotkaniem, rozmową, dialogiem pomiędzy pracownikiem socjalnym a człowiekiem oczekującym na pomoc, by doświadczyć procesu empowerment. Od strony klienta pomocy społecznej poniekąd jest to dramat zguby i ocalenia. Ważne jest uczestnictwo w tym dramacie. Może i powinno stać się ono „przyswajaniem siebie” z uwagi na nadzieję ocalenia. W przekonaniu ks. Tischnera, człowiek w perspektywie zguby i ocalenia jest w stanie siebie przyswoić, gdyż jest bytem-dla-siebie. Chodzi więc nie o pracę socjalną jako taką, ale o jej ,jakość", by wpisywała się w nadzieję ocalenia, a nie logikę zguby. W tym sensie nie sposób nie postrzegać jej także, a może nawet przede wszystkim, jako dramatu moralnego.

Czym jest dramat moralny? Można powiedzieć, iż niemal każda ludzka decyzja polegająca na wyborze dobra lub zła stanowi rodzaj dramatu. Joseph Ratzinger, obecny papież emeryt Benedykt XVI, podejmując próbę rozeznania

8 Na temat filozofii spotkania, jej głównych nurtów, zob. M. Buber, Ja i Ty, tłum. J. Doktór, Warszawa 1993; F. Rosenzweig, Gwiazda zbawienia, tłum. T. Gadacz, Kraków 1998; E. Levinas, Całość i nieskończoność. Esej o zewnętrzności, tłum. M. Kowalska, Warszawa 2002; Filozofia dialogu, wybór, oprac. i wstęp B. Baran, Kraków 1991.

9 J. Tischner, Filozofia..., dz. cyt., s. 10. 
tegoż dramatu, napisał: „W świecie opartym na kalkulacji przewiduje się następstwa i określa, co należy uważać za moralne, a co nie. W ten sposób kategoria dobra znika [...]. Nic w sobie nie jest dobre albo złe, wszystko zależy od następstw działania, które można przewidzieć"10. Tego rodzaju mentalność sprawia, że współczesna euroatlantycka kultura, także kultura życia społecznego, zdaje się już nie dopuszczać żadnej instancji moralnej poza ludzkim wyrachowaniem. Oparte jest ono przede wszystkim na oświeceniowej koncepcji wolności, której idea jest wszakże zagmatwana ${ }^{11}$, co w przekonaniu Ratzingera prowadzi do swego rodzaju dogmatyzmu. Ostatecznie okazuje się on coraz bardziej wrogi samej wolności, gdyż promując wolność niczym nieograniczoną, prowadzi w końcu do jej autodestrukcji ${ }^{12}$.

Dogmatyzacja wolności to nic innego jak jej absolutyzacja. Wiele razy ostrzegał przed nią Jan Paweł II, przypominając ważną zasadę: „Tylko wolność podporządkowana prawdzie prowadzi osobę ludzką ku autentycznemu dobru"13. Jest to szczególnie ważne w odniesieniu do sceny dramatu, jakim jest praca socjalna. W tym kontekście nie chodzi o pracę socjalną jako taką, ale o jej „jakość”, by wpisywała się w nadzieję ocalenia, a nie logikę zguby. W szczególności prawda, będąca przedmiotem dialogu podejmowanego w ramach pracy socjalnej, powinna być naznaczona nadzieją ocalenia. Taką prawdę trzeba odnaleźć i rozpoznać, aby następnie podporządkować jej wszelkie działania wiodące do tego, co w pracy socjalnej oznacza empowerment.

Nietrudno zauważyć, że właściwe rozwiązanie niemal każdego problemu w sferze pracy socjalnej sprowadza się w znacznej mierze do kwestii odpowiedniego doboru pracowników socjalnych. Ważne są nie tylko ich kompetencje zawodowe i osobiste predyspozycje, ale także niemałe znaczenie ma całościowy „obraz człowieka”, jakim się posługują. Uzasadnienie realizowanych celów

10 J. Ratzinger, Europa Benedykta w kryzysie kultur (tytuł oryg. L’Europa di Benedetto nella crisi delle culture), tłum. W. Dzieża, wstęp L. Knabit, M. Pera, Częstochowa 2005, s. 47-48.

11 Wprawdzie istnieje dzisiaj „nowa moralność” definiowana przez takie pojęcia jak sprawiedliwość, pokój czy ochrona środowiska naturalnego, które przywołują podstawowe wartości moralne, ale jest to moralność nieokreślona, pozostająca wyłącznie w sferze polityczno-partyjnej w całkowitej uległości wobec legalizmu prawnego. Joseph Ratzinger jest zdania, że ukształtowany na niej moralizm nie ma trwałych podstaw, co sprawia, że z łatwością może on skręcić w stroną anarchizmu czy terroryzmu, stawiając ostatecznie utopię polityczną ponad człowiekiem z jego godnością i wolnością; por. J. Ratzinger, Europa Benedykta w kryzysie..., dz. cyt., s. 44-45, 53.

12 Por. J. Ratzinger, Europa Benedykta w kryzysie..., dz. cyt., s. 54.

13 Jan Paweł II, Encyklika o niektórych podstawowych problemach moralnych nauczania Kościoła Veritatis splendor, Watykan 1993, nr 84; por. Jan Paweł II, Encyklika o wartości i nienaruszalności życia ludzkiego Evangelium vitae, Watykan 1995, nr 19-21. 
pracy socjalnej w gruncie rzeczy zależy od tego, co i jak myśli się o człowieku, zwłaszcza o jego stosunku do drugiego człowieka i do społeczności. Problem jednak tkwi w tym, iż tego rodzaju wyobrażenia nie tworzą zwartego obrazu człowieka, z natury swej są fragmentaryczne. Wynika to z faktu, że człowiek nie mieści się bez reszty w tym świecie i w społeczności, do której przynależy. Transcenduje on wszystko to, co społeczne, a jednocześnie tylko w społeczności może się realizować. W szczególności przerasta on rzeczywistość społeczną, ale jednocześnie nie może się bez niej rozwinąć.

Dlatego napięcie to, będące czymś nieuniknionym, stanowi jakby kamień węgielny całej etyki życia społecznego, w tym etyki pracy socjalnej, i może być postrzegane jako dramat moralny, naznaczony decyzjami czy wyborami pomiędzy dobrem i złem. Jak odróżnić dobre decyzje od złych decyzji? Czy dana decyzja rzeczywiście przyczynia się do realizacji dobra osobowego klienta pomocy społecznej? Są to wszakże decyzje podejmowane przez konkretnych ludzi, pracowników socjalnych, jak i samych zainteresowanych. Otóż dla podejmowania właściwych decyzji konieczny jest dialog, będący procesem rozpoznawania prawdy o dobru; właśnie tym dobru, które może czy powinno być wyzwolone, ujawnione, realizowane, darowane.

\section{Konkluzja}

Na polu pracy socjalnej nieustannie rozgrywa się dramat, który można by kojarzyć ze spotkaniem, rozmową, dialogiem pomiędzy pracownikiem socjalnym a człowiekiem oczekującym na pomoc, by ten doświadczył procesu empowerment. Wedle ujęcia ks. Tischnera, od strony klienta pomocy społecznej poniekąd jest to dramat zguby i ocalenia. Dlatego ważne jest uczestnictwo w tym dramacie, gdyż może ono i powinno stać się „przyswajaniem siebie” z uwagi na nadzieję ocalenia. Wydaje się, iż tej nadziei niepodobna obudzić bez dialogu, w który powinni angażować się wszyscy aktorzy pracy socjalnej.

Nie wystarczą idee i pomysły samych tylko pracowników socjalnych. Nie ma decydującego znaczenia to, co sam tylko człowiek, oczekujący na społeczne wsparcie, myśli o swojej sytuacji. Natomiast jest czymś ogromnie ważnym, aby to myślenie poszczególnych osób o konkretnych sytuacjach czy kwestiach dopełnić myśleniem wspólnym, a więc myśleniem tego, który świadczy pomoc i tego, który pomocy doświadcza. To jest właśnie przestrzeń dramatu, w której dialog, polegający na wspólnym poszukiwaniu właściwych rozwiązań, ma szansę dać nadzieję ocalenia, wprowadzić w proces empowerment.

Chodzi o to, by pogłębiona świadomość roli i miejsca dialogu wyzwoliła otwarcie się na drugiego - egzystencję dramatyczną. Celem jest wszakże po- 
moc społeczna czy praca socjalna. Do jej realizacji potrzebny jest ten, który ją świadczy i ten, który jej doświadcza. Bez otwarcia dialogicznego niepodobna, aby udzielić skutecznej pomocy osobom i rodzinom, wyzwalając w nich zdolności do funkcjonowania w społeczeństwie na miarę godności człowieka; człowieka jako egzystencji dramatycznej. Nie można tego dokonać bez etyki, etyki przyjaznej człowiekowi, ale relacja pomiędzy pracą socjalną a etyką, to już temat na tyle obszerny, że trzeba by go podjąć oddzielnie. 